\title{
Efeito dos ácidos húmicos na inoculação de bactérias diazotróficas endofíticas em sementes de milho
}

\author{
Effect of the humic acids in endophytic diazotrophic bacteria inoculation in corn seeds \\ Patrícia Marluci da Conceição ${ }^{\mathrm{I}}$ Henrique Duarte Vieira' ${ }^{\mathrm{II}}$ Luciano Pasqualoto Canellas ${ }^{\mathrm{III}}$ \\ Fábio Lopes Olivares $^{\mathrm{IV}}$ Priscila Soraia da Conceição $^{\mathrm{V}}$
}

\begin{abstract}
Os ácidos húmicos podem atuar no aumento da RESUMO população de bactérias diazotróficas introduzidas no interior da planta e, consequentemente, no incremento dos efeitos benéficos sobre a planta hospedeira. Com este trabalho, objetivou-se avaliar o efeito dos ácidos húmicos na inoculação de bactérias diazotróficas endofíticas, em sementes de milho. Foi utilizada a estirpe Herbaspirillum seropedicae Z67 BR 11175. A inoculação das sementes com as bactérias e a adição de ácidos húmicos foram realizadas pelo recobrimento das sementes de milho UENF 506-8, com a mistura de calcário, meio de cultura semisólido, água e cimentante. As sementes recobertas foram semeadas em vasos Leonard. Aos 40 dias após a semeadura, as plântulas foram coletadas, e foi realizada a contagem de bactérias nas raízes pela técnica do Número Mais Provável. Os resultados deste trabalho mostram que os ácidos húmicos não interferem negativamente no crescimento das bactérias e estimulam a colonização da microbiota nativa. No entanto, nas condições avaliadas, a aplicação conjunta de bactérias + ácidos húmicos não estimulou o crescimento da população de bactérias inoculadas nas plântulas de milho.
\end{abstract}

Palavras-chave: recobrimento, bactérias diazotróficas, ácidos húmicos, vasos Leonard.

\section{ABSTRACT}

The objective of this research was to evaluate the effect of the humic acids in the inoculation of endophytic diazotrophic bacteria in corn seeds. It was used the bacteria Herbaspirillum seropedicae Z67 BR 11175. The inoculation of the seeds with the bacteria and the addition of humic acids were accomplished by the coating of the corn seeds UENF 506-8. The coating was accomplished with a mixture of lime, semi-solid middle culture, water and cement. The seeds covered were sown in Leonard vases. Forty days after sowing the plants were collected and the bacteria couting was accomplished in the roots by the Most probable Number technique. The results showed that the humic acids doesn't interfere negatively in the bacteria growth of and they stimulate the colonization of the native microbiota. However, in the appraised conditions, the united application of bacteria + humic acids didn't stimulate the growth of the bacteria population inoculated in the corn seedling.

Key words: coating, diazotrophic bacteria, humic acid, Leonard vase.

O uso das bactérias diazotróficas endofíticas representa um grande potencial para reduzir a dependência de fertilizantes nitrogenados sintéticos. $\mathrm{O}$ aumento do custo dos adubos nitrogenados e a preocupação cada vez maior, no exterior e no Brasil, com os possíveis efeitos negativos do excesso de nitrato nos mananciais são fatores que devem ser

IDepartamento de Fitotecnia, Universidade Federal de Viçosa (UFV), 36571-000, Viçosa, MG, Brasil. E-mail: patymarluci@yahoo.com.br. Autor para correspondência.

"Laboratório de Fitotecnia, Produção Vegetal, Universidade Estadual do Norte Fluminense (UENF), Campos dos Goytacazes, RJ, Brasil.

IIILaboratório de Solos, Produção Vegetal, UENF, Campos dos Goytacazes, RJ, Brasil.

${ }^{\mathrm{IV}}$ Laboratório de Biologia Celular e Tecidual, UENF, Campos dos Goytacazes, RJ, Brasil.

vepartamento de Engenharia Civil, UFV, Viçosa, MG, Brasil. 
levados em consideração para o incentivo ao estudo do processo natural de Fixação biológica do Nitrogênio (FBN) (CANTARELLA\& DUARTE, 2004). Assim, todas as possibilidades de incremento da FBN na agricultura devem ser exploradas, não somente como alternativa econômica, mas também ecológica (CANUTO, 2003).

Estudos envolvendo bactérias fixadoras de nitrogênio associadas às Poáceas (como milho, trigo, arroz, cana-de-açúcar) iniciaram-se no Brasil, em 1956. Na década de 80, foi comprovado, com ajuda de novas técnicas de quantificação, que algumas dessas espécies de plantas podem obter contribuições significativas de nitrogênio com a atividade desses microrganismos (BODDEY \& DÖBEREINER, 1988). Os microrganismos diazotróficos endofíticos apresentam grande potencial na FBN devido a habilidade que apresentam para colonizar toda a planta e estabelecer-se dentro de nichos protegidos do oxigênio ou de outros fatores, podendo expressar seu grande potencial para fixação de nitrogênio em grau máximo (KENNEDY et al., 1997). Esses microrganismos penetram na planta hospedeira pelas aberturas naturais e injúrias. Nas raízes, um dos sítios de entrada mais utilizados pelas bactérias endofíticas são as injúrias causadas pela emergência de raízes laterais (CERIGIOLI, 2006).

Os ácidos húmicos podem atuar no aumento da população de bactérias diazotróficas introduzidas no interior da planta e, consequentemente, no incremento dos efeitos benéficos sobre a planta hospedeira (MARQUES JÚNIOR, 2006). Isso pode ser hipoteticamente explicado como parte dos efeitos dos ácidos húmicos que promovem o crescimento vegetal pelo maior enraizamento e aumentam o número de sítios de mitose e emergência de raízes laterais, aumentando o número de pontos de infecção para as bactérias.

Com este trabalho, objetivou-se avaliar o efeito dos ácidos húmicos na inoculação de bactérias diazotróficas endofíticas, em sementes de milho.

As avaliações foram realizadas em casa de vegetação do Centro de Ciências e Tecnologias Agropecuárias (CCTA) da Universidade Estadual do Norte Fluminense Darcy Ribeiro (UENF), em Campos dos Goytacazes, Rio de Janeiro (RJ). Foi utilizada, neste estudo, a estirpe de Herbaspirillum seropedicae Z67 (BR 11175) proveniente da coleção de bactérias diazotróficas da Embrapa Agrobiologia, Município de Seropédica, RJ.

Para a preparação do inóculo das bactérias, uma colônia da estirpe foi inoculada em meio DYGS líquido (RODRIGUES NETO et al., 1986) e permaneceu sob agitação a $150 \mathrm{rpm}$, por $24 \mathrm{~h}$, a $30^{\circ} \mathrm{C}$. Uma alíquota de $30 \mu \mathrm{L}$ da cultura crescida foi transferida para frascos de vidro (volume $12 \mathrm{~mL}$ ) contendo $5 \mathrm{~mL}$ de meio $\mathrm{JNFb}$ semisólido (BALDANI et al., 1992). Os frascos foram incubados para o crescimento e formação da película por $72 \mathrm{~h}$, a $30^{\circ} \mathrm{C}$. Em parte dos frascos de vidro, houve adição de ácidos húmicos extraídos de vermicomposto, na concentração de $40 \mathrm{mg} \mathrm{L}^{-1}$. O procedimento de extração foi realizado de acordo com as recomendações da International Humic Substances Society (IHSS) (CERETTA, 1995).

A inoculação das sementes com as bactérias e a adição de ácidos húmicos foram realizadas pelo recobrimento das sementes de milho (UENF 506-8) com a mistura de $70 \%(\mathrm{p} / \mathrm{p})$ de calcário, $10 \%(\mathrm{p} / \mathrm{p})$ de meio de cultura semisólido JNFb e $20 \%$ (p/p) de água destilada. Foram adicionados a essa mistura $2 \%$ de agente cimentante (cola à base de acetato de polivinila).

Os tratamentos avaliados foram: $\mathrm{T} 1$ : sementes recobertas com meio de cultura JNFb semisólido sem adição de bactérias e ácidos húmicos (Controle); T2: sementes recobertas com meio de cultura $\mathrm{JNFb}$ semisólido + ácidos húmicos; T3: sementes recobertas com meio de cultura JNFb semisólido + bactérias e T4: sementes recobertas com meio de cultura JNFb semisólido + ácidos húmicos + bactérias.

As sementes recobertas foram semeadas em vasos Leonard com areia, quatro sementes por vaso. Aos sete dias após a semeadura, foi realizado um desbaste, selecionando duas plântulas por vaso. Os vasos foram mantidos em casa de vegetação e irrigados diariamente com $150 \mathrm{~mL}$ de solução nutritiva desenvolvida por FURLANI \& FURLANI (1988). Aos 40 dias após a semeadura, as plântulas foram coletadas. Foi realizada a contagem de bactérias nas raízes das plântulas pela técnica do Número Mais Provável (NMP), estimada pela formação de película típica no meio JNFb, usando a tabela McCrady, para três repetições por diluição (DÖBEREINER et al., 1995).

O experimento foi instalado em delineamento inteiramente casualizado. Os resultados provenientes das avaliações foram submetidos à análise de variância, e as médias dos tratamentos foram comparadas pelo Teste de Tukey, a 5\% de probabilidade.

Ocorreu um aumento significativo no número de bactérias, nos tratamentos com adição de bactérias, ácidos húmicos e uso em conjunto de bactérias + ácidos húmicos em relação ao controle de plântulas de milho (Figura 1). Os ácidos húmicos não interferiram negativamente no crescimento das bactérias endofíticas, pois o tratamento com uso conjunto de bactérias + ácidos húmicos não diferiu do tratamento com adição de bactérias. MARQUES JÚNIOR (2006), avaliando o efeito dos ácidos húmicos na sobrevivência da bactéria $\boldsymbol{H}$. seropedicae Z67 no solo, também verificou que os ácidos húmicos não 


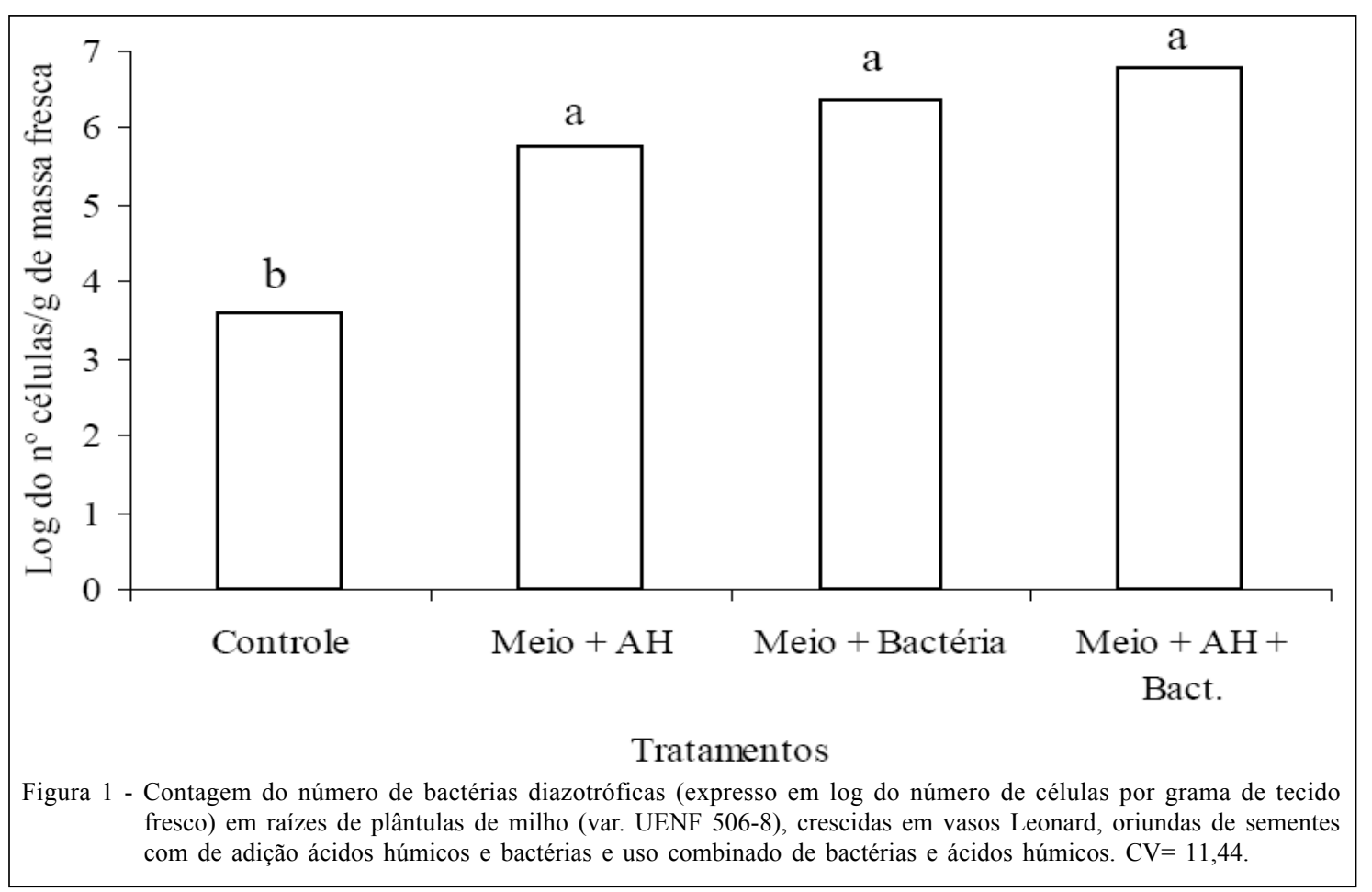

interferem negativamente no crescimento bacteriano. Além disso, este afirma que, em determinadas concentrações, os ácidos húmicos podem estimular o crescimento de microrganismos endofíticos. Segundo MARQUES JÚNIOR (2006), as bactérias não utilizam os ácidos húmicos como fonte de carbono, mas podem utilizá-lo como fonte de nitrogênio, embora a atividade da nitrogenase não seja afetada. No entanto, nas condições avaliadas, a aplicação conjunta de bactérias + ácidos húmicos não estimulou o crescimento da população de bactérias inoculadas nas plântulas de milho (Figura 1).

Nos tratamentos onde não houve inoculação de bactérias, controle e meio + ácidos húmicos, houve a presença de bactérias diazotróficas, provavelmente, devido à contaminação natural dos tecidos por outros microrganismos diazotróficos capazes de sobreviver em outros ambientes que não endofíticos, como no solo, os quais podemos chamar de microbiota nativa. A presença de microrganismos em tecidos de plantas não inoculadas é comum, já que os meios utilizados na técnica do NMP não são seletivos para H. seropedicae Z67, mas semiseletivos, podendo detectar a presença de outros microrganismos diazotróficos (CANUTO, 2003).

Os ácidos húmicos estimularam o crescimento da microbiota nativa, como podemos evidenciar pelos resultados da técnica do NMP, os quais mostraram um aumento de duas unidades logarítmicas do tratamento com adição de ácidos húmicos, sem a inoculação de bactérias, em relação ao controle (Figura 1). Segundo FAÇANHA et al. (2002) e CANELAS et al. (2002), os ácidos húmicos apresentam grupamentos auxínicos em sua estrutura, os quais ativam as bombas de $\mathrm{H}^{+}$-ATPase da membrana plasmática. Esse fato promove a acidificação do apoplasto e o consequente aumento da plasticidade da parede celular, resultando no incremento da área e no comprimento radicular. Assim, os ácidos húmicos podem atuar no aumento da população de bactérias diazotróficas no interior da planta, aumentando o número de raízes laterais, as quais se constituem em pontos de infecção da planta hospedeira pelas bactérias.

A inoculação com H. seropedicae (Z67), nos dois tratamentos onde houve adição de bactérias pelo recobrimento de sementes, promoveu incremento de três unidades logarítmicas em relação às plântulas controle. Assim, o recobrimento mostra-se como um meio de inoculação viável para bactérias diazotróficas endofíticas da espécie Herbaspirillum seropedicae (Z67), o que garante a sobrevivência dessas bactérias, no recobrimento, até a emissão das raízes pelas plantas, como observado por CONCEIÇÃO et al. (2008).

Os resultados deste trabalho mostram que os ácidos húmicos não interferem negativamente no 
crescimento das bactérias e estimulam a colonização da microbiota nativa. No entanto, nas condições avaliadas, a aplicação conjunta de bactérias + ácidos húmicos não estimulou o crescimento da população de bactérias inoculadas nas plântulas de milho. Assim, novas pesquisas devem ser realizadas para estudar outras concentrações de ácidos húmicos mais adequadas, visando ao aumento da inoculação das bactérias diazotróficas endofíticas da espécie Herbaspirillum seropedicae (Z67).

\section{REFERÊNCIAS}

BALDANI, V.L. et al. Identification and ecology of Herbaspirillum seropedicae and the closely related Pseudomonas rubrisubalbicans. Symbiosis, v.13, p.65-73, 1992.

BODDEY, R.M.; DÖBEREINER, J. Nitrogen fixation associated with grasses and cereal: recent results and perspectives for future research. Plant and Soil, v.108, p.53-65, 1988. Disponível em: <http:// www.springerlink.com.w10041.dotlib.com.br/content/u125xx7k675j/

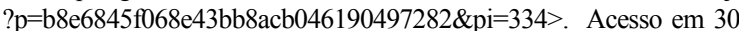
de abril de 2009. Doi: 10.1007/BF02370099.

CANELLAS, L. P. et al. Humic acids isolated from earthworm compost enhance root elongation, lateral root emergence, and plasma membrane $\mathrm{H}^{+}$-ATPase activity in maize roots. Plant Physiology, v.130, p.1951-1957, 2002.

CANTARELLA, H.; DUARTE, A.P. Manejo da fertilidade do solo para a cultura do milho. In: GALVÃO, J.C.C.; MIRANDA, G. V. Tecnologias de Produção do milho. Viçosa, MG: UFV, 2004. p.139-182.

CANUTO, E.L. Seleção de bactérias diazotróficas endofíticas para uso com insumo biológico em plantas de cana-de-açúcar oriundas de sementes. 2003. $72 \mathrm{f}$. Dissertação (Mestrado em Agronomia) - Universidade Federal Rural do Rio de Janeiro, Seropédica.

CERETTA, C.A. Fracionamento de $\mathbf{N}$ orgânico, substâncias húmicas e caracterização de ácidos húmicos de solo em sistemas de cultura sob plantio direto. 1995. 150f. Tese (Doutorado em Ciências do solo) - Universidade Federal do Rio Grande do Sul, Porto Alegre.
CERIGIOLI, M.M. Diversidade de bactérias endofíticas de raízes de milho (Zea Mays L.) e potencial para promoção de crescimento. 2006. 132f. Tese (Doutorado em Ciências Biológicas) - Universidade Federal de São Carlos, São Carlos.

CONCEIÇÃO, P.M. et al. Recobrimento de sementes de milho com ácidos húmicos e bactérias diaziotróficas endofíticas. Pesquisa agropecuária brasileira, v.43, n.4, p.545-548, 2008. Disponível em: <http://www.scielo.br/scielo.php?pid=S0100$204 X 2008000400015 \&$ script $=$ sci arttext $>$. Acesso em $18 \mathrm{de}$ março de 2009. Doi: 10.1590/S0100-204X2008000400015.

DÖBEREINER, J. et al. Como isolar e identificar bactérias diazotróficas de plantas não-leguminosas. Brasília: EMBRAPA-SPI: Itaguaí-RJ. EMBRAPA-CNPAB, 1995. 60p.

FAÇANHA, A.R. et al. Bioatividade de ácidos húmicos: efeitos sobre o desenvolvimento radicular e sobre a bomba de prótons da membrana plasmática. Pesquisa Agropecuária Brasileira, v.37, n.9, p.1301-1310, 2002. Disponível em: <http:// www.scielo.br/scielo.php?script $=$ sci_arttext\&pid $=\mathrm{S} 0100$ $204 X 2002000900014 \& \operatorname{lng}=$ en $\& n r m=i s o \&$ tlng $=p t>$. Acesso em 18 de março de 2009. Doi: 10.1590/S0100$204 \times 2002000900014$.

FURLANI, A. M. C.; FURLANI, P. R. Composição e pH de soluções nutritivas para estudos fisiológicos e seleção de plantas em condições nutricionais adversas. Campinas, SP: Instituto Agronômico, 1988. 34p. (Boletim Técnico n. 121).

KENNEDY, I.R. et al.. Biological nitrogen fixation in nonlegumes field crops: facilitating the evolution of in effective association between Azospirillum and wheat. Plant and Soil, v.194, p.65-79, 1997.

MARQUES JÚNIOR, R.B. Potencial do uso combinado de substâncias húmicas e bactérias diazotróficas endofíticas para bioestimulação de plantas. 2006. 88f. Dissertação (Mestrado em Produção Vegetal) - Universidade Estadual do Norte Fluminense Darcy Ribeiro, UENF, Campos dos Goytacazes.

RODRIGUES NETO, J. et al. Meio simples para o isolamento e cultivo de Xanthomonas campestris pv. citri Tipo B. Suma Phytopathologica, v.12, p.16, 1986. 